\title{
Research on cooperative-based listening and speaking English teaching mode and application for fuzzy mathematics
}

\author{
Wei Dong, Yan Ding \& Ying Shi \\ Qinhuangdao Institute of Technology, Qinhuangdao, Hebei, China
}

\begin{abstract}
At present, listening and speaking English textbooks in Chinese Universities have an extensive use of cooperative learning strategies. How to build a cooperative learning mechanism that is applicable for listening and speaking English teaching mode, in order to promote that the integration with western learning strategies and China's college English listening and speaking teaching moves from the textbook representation to the reality of textbooks is an avoidable subject for each college English teacher. This paper starts from the basic theory of "cooperative" teaching mode, and then analyzes the status quo of academic English listening and speaking in regular colleges, and finally carries out comparative analysis by the use of fuzzy mathematics method based on the traditional listening and speaking English teaching mode and cooperative listening and speaking English teaching mode and other methods, and finally concludes the main trend of future development of the cooperative listening and speaking English teaching mode.
\end{abstract}

Keywords: cooperative; listening and speaking English teaching mode; comparative analysis

\section{INTRODUCTION}

It is necessary to reform the college English classroom teaching. In the $21^{\text {st }}$ century, human beings enter an international high-tech economy age, information age, intelligence and talent competition age. In terms of language teaching, what should we do? People's perspective has an important shift. Simply speaking, the emphasis is converted from viewing the language as a form of learning and practice (grammar and vocabulary) to viewing the language as a function system used to realize multiple interpersonal purposes (Tarone Elaine, Geroge Yule, 1999). Later, there are a large number of English education and learning theories, which are focused on changing the traditional teaching, and paying too much emphasis on explanation of grammar and vocabulary, but ignore the tendency to cultivate the students' ability to practically use language, and be student-oriented to develop students' creative thinking and creative ability. However, the cooperative English teaching mode conforms to the development trend of the times, which is student-oriented to comprehensively cultivate the students' listening and speaking English ability from many aspects. Therefore, it is particularly important to research the cooperative listening and speaking English learning mode.

After practice survey, Ma Lan finds that, many teachers view the implementation of the cooperative teaching mode as the pursuit of changing the classroom teaching behavior, resulting that the cooperative learning is very lively and extraordinary in the form, but in fact the students fail to learn substantial knowledge in this process, because the cooperative learning should not be confined to the form of teaching organization in the classroom, but need to share learning content and resources in real life.

Zeng Qi pointed out that the teachers have one-sided understanding of the cooperative teaching mode in theory, and have certain errors in the practice and use of cooperative learning in actual teaching, resulting in the superficial form of implementation of cooperative learning, thus affecting the comprehensive development of students' English learning.

Wang Tan has extensive cognition in the research field of cooperative learning, who believes that learning is an interaction of information, but also a kind of interpersonal communication. The interaction process involves in the interaction between teachers and teachers, interaction between students and students, interaction between teachers and students, and a vari- 
ety of complex interactive mode. The cooperative teaching is to focus the interactive center on expansion of the relationship between students, but it is often ignored by people in actual teaching. He believes that, in the cooperative teaching, mutual exchange and debate among group members in the cooperative learning can jointly improve learning. He advocates that the teachers should be good "directors" in classroom teaching, and the students should be good "actors". A great number of classroom time should be left to the students, so that the students can have an opportunity to express themselves, and let them learn from each other, and ultimately achieve common purpose of improvement.

Based on previous researches, this paper illustrates the shortcomings of the traditional English teaching mode, and carries out analysis by the use of the cooperative listening and speaking English teaching mode emerging in recent years, and compares with the traditional teaching mode, and finally obtains realistic results, thus providing guidance for future research in related fields.

\section{TRADITIONAL LISTENING AND SPEAKING ENGLISH TEACHING MODE}

This paper summarizes the shortcomings of the traditional teaching mode according to the traditional teaching mode as follows:

(1) The traditional classroom teaching goal is oversimplified

The teachers "prepare for" the teaching goal in lesson preparation, and just simply repeat in class, and even do not repeat, but just believe that they know fairly well, and they can explain knowledge with a purpose. In fact, the students are far from understanding of the goal, so it is needless to know fairly well. Therefore, the students do not know what knowledge to grasp in class.

(2) The students learning is free of independence

The teachers believe what are known or unknown by the students, what are the key points and what are the difficult points from their own subjective consciousness, but they do not take into account the needs of students. For example, the teachers believe that "set out" is very important, and explain repeatedly, but the students have mastered the usage and collocation of this phrase. The teachers waste time in class, but they fail to explain something to be learnt by the students, resulting in a low efficiency of learning, high investment and low output. The regular learning is determined by the teachers' subjective consciousness. The students do not have their independence, and have been in a state of passive learning, and lack of initiative.

(3) The students are lack of cooperative awareness Nowadays, the social division of labor is increasingly refined, which requires that people have a sense of cooperative awareness. However, the regular education process ignores the cultivation of this capability.

\section{(4) Simplicity of evaluation}

The final evaluation of the students just looks at the examination score of students, and evaluates the students' performance via score, does not care about the students' growth process, ignores the process, but only focuses on results. It could not stimulate the students' intrinsic motivation, so that the students learning is lack of long-term power, and the students could not develop the habit of lifelong learning.

(5) Failure to focus on capacity cultivation

Too many students can get high scores in examination, but they are at mass when they read or translate articles, not to mention blurting out the authentic speaking skills.

\section{COOPERATIVE LISTENING AND SPEAKING ENGLISH TEACHING MODE}

\subsection{Connotation and basis of cooperative teaching mode}

Cooperative learning was originated in the 1970s, which is one of the most common fields in the current language education theory and practice. Slavin R.E. thinks that the cooperative learning refers to learning in the group and being engaged in the related activities, thus ultimately obtaining the teaching technology approved by the classroom. In China, the cooperative teaching mode was originated in the 1980s, but it has obtained a rapid development in this century. Wang Tan believes that "the cooperative teaching mode is a kind of teaching strategy, which is aimed at promoting the students to achieve common learning goals by mutual cooperation, and finally consider the total score of a group as the reward basis (2003)". The traditional listening and speaking English teaching mode has been intensified in various colleges and universities, while the cooperative listening and speaking English teaching mode fails to be implemented in many regular institutions.

\subsection{Analysis of status quo of listening and speaking English teaching in regular colleges}

\subsubsection{The students have a weak foundation in English} The students in regular colleges have a relatively weak foundation in English with respect to the students in key colleges, so they have a relatively strong dependence on the teachers teaching, and a large part of students view English class as a sole path of English learning, thus resulting in teaching obstacles. In addition, some students are lack of confidence due to poor English, and dare not to express themselves, resulting in the loss of interest in the process of English learn- 
ing. The cooperative teaching mode requires that all of the group members need to rely on their own efforts to find and solve problems in class and after class. In this process, English listening and speaking and writing can be greatly improved, so as to provide possibility to change the situation of poor listening and speaking English learning of students in regular colleges.

\subsubsection{The teachers are lack of experience}

The cooperative listening and speaking English teaching mode emphasizes to be student-oriented, thus getting rid of the present situation of most students in regular college solely relying on the teachers in classroom. English teachers in regular colleges are commonly young teachers, and they have a very strong subjectivity in the evaluation of the students listening and speaking tasks, and have insufficient experience, thereby restricting the students' interest and enthusiasm of English learning.

\section{DESIGN OF COOPERATIVE LISTENING AND SPEAKING ENGLISH TEACHING MODE}

The main framework of cooperative listening and speaking English teaching mode is shown as follows:

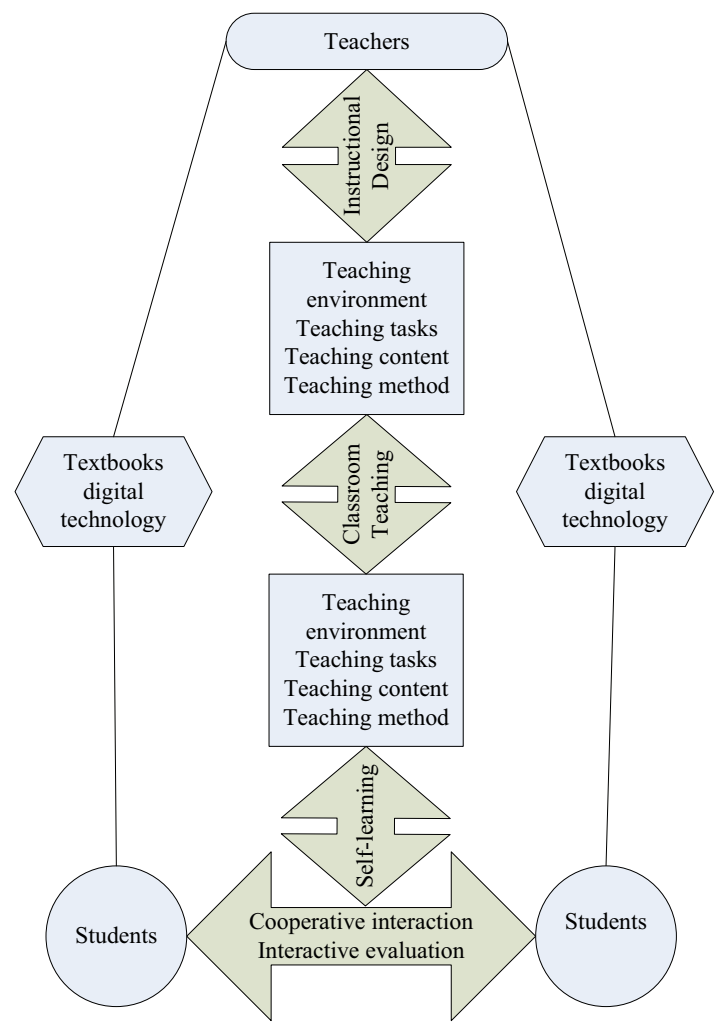

Figure 1. Overall framework of cooperative teaching mode

\subsection{Preparatory stage before class}

The teaching goal in this phase is mainly to understand the purpose and meaning of teamwork, and expand horizon of listening and speaking English through looking up the relevant books and materials by the students. In the cooperative teaching, it is mainly divided into two parts:

i. The teachers group the students, and assign different tasks for each group, and then respectively introduce the cases and role of teamwork. In this process, the teachers also need to prepare for the materials, and develop the judgment criteria of the relevant matters in advance.

ii. The students should look for materials according to the tasks assigned by the teachers. The cooperative learning method is to group students to collect and organize materials, and then produce PPT and internal drills draft and so on.

\subsection{Classroom presentation and evaluation}

The main goal in this phase is to exercise the students' listening and speaking skills. The content can be further analyzed through the demonstration of the students and exchange between groups. The demonstration and questions can be adopted to promote and improve the students' English listening and speaking skills, exercise the group's cooperative awareness, so as to develop a good habit of English learning. In this process, the teachers should make appropriate guidance, and demonstrate the cooperative English learning mode based on the groups, and then other groups should make appropriate notes and ask questions to the demonstration group, and then the teachers should make appropriate evaluation and scoring according to the process of demonstration prepared by each group.

\subsection{Attentions in the process of implementation of cooperative listening and speaking English teaching mode}

\subsubsection{The evaluation criteria should have rationality} The evaluation of English listening and speaking performance is different from the evaluation of grammar and writing performance. The teachers have a very strong subjective initiative. Reasonable and fair evaluation enables the students to enhance self-confidence, so that the students generate motivation to learn English, and the teachers should make reasonable evaluation criteria. In classroom, in the process of English demonstration by the students, the teachers should not only evaluate the correctness of the students' speech speed, voice, tone and expression, but also evaluate the cooperative spirit of the group and cooperative awareness of the group, and should be based on the principle of inspiration and praise in the entire process of evaluation, thus encouraging every student have an idea and desire to be positively involved in expression, and ultimately let the students become "winners" in the cooperative listening and speaking English learning, so that the students are more willing to learn and communicate in English, thus achieving the purpose 
of cooperative listening and speaking English teaching.

\subsubsection{Establishment of team spirit}

The construction process of the cooperative listening and speaking English teaching mode is integrated with the group concept in a certain extent. The cooperative learning group has a high cohesion and clear learning objectives, which can make every member find the appropriate sense of belonging. In the process of English teaching in regular colleges and universities, the students should develop a good habit of English learning, and improve interpersonal skills, of which the most important is to highlight the sense of teamwork.

\subsubsection{The cooperative learning process needs to be clear and workable}

The biggest obstacle for the students to learn English in regular colleges is relatively weak foundation in English, resulting in learning difficulties. If the content of cooperative teaching mode is too complex, and the steps are too complicated, it will reduce the students' enthusiasm, thereby significantly reducing the students' enthusiasm and confidence in English learning. Meanwhile, the main purpose of listening and speaking teaching is to exercise students' communicative competence, but the students could not give up the opportunity of communication due to too complex content.

\subsubsection{Reasonable allocation of group members}

The allocation of group members is essential in the cooperative listening and speaking English learning. One person with a strong communication and leadership should be selected as a group leader. The selection of the group leader is the most important, which is related to the implementation of whether the group can achieve that every student is involved in its true sense. Therefore, as a leader of the group, he /she should play a positive role in learning and life, and lead the entire group to be positive. For the constitution of the group members, there is also a need to have containment between members. It requires that the students enter in the group voluntarily, so that the teachers can make some adjustments, and then each group strives to complete the purpose of the cooperative listening and speaking English teaching.

\section{COMPARATIVE ANALYSIS OF COOPERA- TIVE LISTENING AND SPEAKING ENGLISH TEACHING MODE BASED ON FUZZY MATHEMATICS}

The concept of fuzzy mathematics was first proposed by an American mathematician and professor, L.A. Zadeh based on the computer mathematics. After the development, the fuzzy mathematics is used in various fields, and the fuzzy mathematics can be used to research the impact of the collaborative listening and speaking English teaching mode, exploratory listening and speaking English teaching mode, interactive listening and speaking English teaching mode and cooperative listening and speaking English teaching mode. The steps are as follows:

\subsection{Establishment of fuzzy matrix}

After the experts scoring the collaborative listening and speaking English teaching mode, exploratory listening and speaking English teaching mode, collaborative listening and speaking English teaching mode and traditional listening and speaking English teaching mode, three fuzzy matrices can be obtained as follows:

Table 1. Score of cooperative teaching mode

\begin{tabular}{l|lllll}
\hline (Cooperative) & $\begin{array}{l}\text { Very } \\
\text { high }\end{array}$ & $\begin{array}{l}\text { Relatively } \\
\text { high }\end{array}$ & High & $\begin{array}{l}\text { Relatively } \\
\text { low }\end{array}$ & Low \\
\hline$P_{1}$ & 0.38 & 0.21 & 0.19 & 0.14 & 0.08 \\
$P_{2}$ & 0.45 & 0.17 & 0.2 & 0.12 & 0.06 \\
$P_{3}$ & 0.4 & 0.18 & 0.13 & 0.28 & 0.01 \\
$P_{4}$ & 0.28 & 0.24 & 0.25 & 0.17 & 0.06 \\
\hline
\end{tabular}

Table 2. Score of exploratory teaching mode

\begin{tabular}{l|lllll}
\hline (Exploratory) & $\begin{array}{l}\text { Very } \\
\text { high }\end{array}$ & $\begin{array}{l}\text { Relatively } \\
\text { high }\end{array}$ & High & $\begin{array}{l}\text { Relatively } \\
\text { low }\end{array}$ & Low \\
\hline$P_{1}$ & 0.30 & 0.33 & 0.14 & 0.22 & 0.01 \\
$P_{2}$ & 0.49 & 0.19 & 0.3 & 0.02 & 0 \\
$P_{3}$ & 0.28 & 0.24 & 0.25 & 0.17 & 0.06 \\
$P_{4}$ & 0.39 & 0.19 & 0.18 & 0.23 & 0.02 \\
\hline
\end{tabular}

Table 3. Score of collaborative teaching mode

\begin{tabular}{l|lllll}
\hline (Collaborative) & $\begin{array}{l}\text { Very } \\
\text { high }\end{array}$ & $\begin{array}{l}\text { Relatively } \\
\text { high }\end{array}$ & High & $\begin{array}{l}\text { Relatively } \\
\text { low }\end{array}$ & Low \\
\hline$P_{1}$ & 0.26 & 0.32 & 0.15 & 0.19 & 0.08 \\
$P_{2}$ & 0.18 & 0.48 & 0.13 & 0.17 & 0.04 \\
$P_{3}$ & 0.29 & 0.16 & 0.22 & 0.21 & 0.12 \\
$P_{4}$ & 0.50 & 0.21 & 0.16 & 0.11 & 0.02 \\
\hline
\end{tabular}

Table 4 Score of traditional teaching mode

\begin{tabular}{l|cccll}
\hline (Traditional) & $\begin{array}{l}\text { Very } \\
\text { high }\end{array}$ & $\begin{array}{l}\text { Relatively } \\
\text { high }\end{array}$ & $\begin{array}{l}\text { High } \\
\text { Relatively }\end{array}$ & Low \\
\hline$P_{1}$ & 0.27 & 0.31 & 0.17 & 0.19 & 0.08 \\
$P_{2}$ & 0.25 & 0.20 & 0.19 & 0.18 & 0 \\
$P_{3}$ & 0.29 & 0.16 & 0.22 & 0.21 & 0.12 \\
$P_{4}$ & 0.48 & 0.18 & 0.13 & 0.17 & 0.04 \\
\hline
\end{tabular}

\subsection{Calculation of index weight}

Weight vector, $A, A=\left(a_{1}, a_{2}, \ldots a_{n}\right)$, of which $a_{i}$ represents the distribution of the importance of the indicators of the listening and speaking English teaching 
mode. The weight can be calculated by the hierarchical mathematical analysis method.

First, the figures from 1 to 9 construct the judgment matrix. The constructed judgment matrix is as follows:

Table 5. Judgment matrix table

\begin{tabular}{l|llll}
\hline & $P_{1}$ & $P_{2}$ & $P_{3}$ & $P_{4}$ \\
\hline$P_{1}$ & 1 & 2 & 1 & 3 \\
$P_{2}$ & $1 / 2$ & 1 & $1 / 2$ & 2 \\
$P_{3}$ & 1 & 2 & 1 & 2 \\
$P_{4}$ & $1 / 3$ & $1 / 2$ & $1 / 2$ & 1 \\
\hline
\end{tabular}

\subsection{Consistency test and weight vector}

The calculation methods of the consistency index of the judgment matrix $C I$ and the consistency ratio of the judgment matrix $C R$ are shown as follows

$C I=\frac{\lambda_{\max }-n}{n-1}$

Where, $n$ represents the order number of the judgment matrix, that is, the number of comparison factors.

$$
C R=\frac{C I}{R I}
$$

When $C R \geq 0.1$, the inconsistency of the matrix is unacceptable, and the data of the judgment matrix needs to be adjusted. When $C R \leq 0.1$, the judgment matrix can be considered as the consistency matrix.

Table 6. Consistency test and weight result table

\begin{tabular}{lllcl}
\hline & $P_{1}$ & $P_{2}$ & $P_{3}$ & $P_{4}$ \\
\hline$w$ & 0.356 & 0.194 & 0.325 & 0.125 \\
$\lambda$ & & & 4.046 & \\
$C I$ & & & 0.015 & \\
$C R$ & & & 0.017 & \\
\hline
\end{tabular}

\subsection{Calculation results}

The vector $A$ and fuzzy matrix can be calculated by the above method. The vector $B=\left(b_{1}, b_{2}, \ldots b_{m}\right)$ can be obtained by composition of $A$ and $R$ by the use of the composition operator $M(\bullet, \oplus)$.

$B=A O R=\left(\begin{array}{llll}a_{1} & a_{2} & a_{3} & a_{4}\end{array}\right) O\left(\begin{array}{ccccc}r_{11} & r_{12} & & \cdots & r_{15} \\ r_{21} & r_{22} & & \cdots & r_{25} \\ \vdots & \vdots & \vdots & \ddots & \vdots \\ r_{41} & r_{42} & & \cdots & r_{45}\end{array}\right)$

Where, there are a total of five fuzzy matrices, and

$$
\begin{aligned}
& d_{j}=\left(d_{1} \bullet r_{1 j}\right)+\left(\underset{*}{d_{2}} \bullet r_{2 j}\right)+\cdots+\left(d_{n} \bullet r_{n j}\right), \\
& (j=1,2, \cdots m)
\end{aligned}
$$

After calculation, the fuzzy evaluation vector of the practice factor in reflection

$B_{1}=\left(\begin{array}{llll}0.39 & 0.20 & 0.18 & 0.19\end{array}\right)$

Similarly, the fuzzy evaluation vectors of other factors are respectively as follows

$$
\begin{aligned}
& B_{2}=\left(\begin{array}{llll}
0.34 & 0.26 & 0.21 & 0.17
\end{array}\right) \\
& B_{3}=\left(\begin{array}{llll}
0.28 & 0.29 & 0.17 & 0.18
\end{array}\right)
\end{aligned}
$$

$B_{4}=\left(\begin{array}{llll}0.30 & 0.22 & 0.19 & 0.19\end{array}\right)$

$B_{5}=\left(\begin{array}{llll}0.2106 & 0.1973 & 0.2072 & 0.2059\end{array}\right)$

Assuming that, in each teaching mode table, the weight value of the factor:

$\alpha=\left(\begin{array}{llllll}0.2 & 0.2 & 0.15 & 0.15 & 0.15 & 0.15\end{array}\right)$

To calculate the all vector matrix of the factor and evaluation vector matrix obtained from fuzzy evaluation, and calculate the impact of listening and speaking English teaching mode, the results are as follows

$$
B=\left(\begin{array}{lllll}
0.31 & 0.23 & 0.19 & 0.19 & 0.08
\end{array}\right)
$$

According to the above results, the number of people who recognize the cooperative listening and speaking English teaching mode accounts for $31 \%$ of all the population. Based on the principle of maximum membership of fuzzy mathematics, the judgment result is very high, while the traditional listening and speaking English teaching mode is relatively low.

\section{CONCLUSION}

The cooperative learning provides a platform for each student to participate in listening and speaking English. This teaching method can not only improve English level of students in regular colleges, but also cultivate their interpersonal skills and improve students' team spirit, and completely change the traditional English teaching mode and students learning state. Finally, by the use of the comparative method, the cooperative listening and speaking English teaching mode will become the main trend of future development, thus providing possibility for the English teaching in regular colleges to move towards a new level.

\section{REFERENCES}

[1] Deng Yingling. 2009. Application for three-dimensional teaching mode in "English viewing, listening and speaking" teaching under the network environment. Foreign Language and Foreign Language Teaching, (11). 
[2] Chu Fengchun, Wang Xueqin. 2012. To create language atmosphere and cultivate learning interest. Campus English: Teaching and Research Edition, (11): 12-16.

[3] Sun Qiantu. 2002. Research and practice of "cooperative learning" mode in senior high school English classroom teaching. English Teaching in Primary and Secondary School and Research, (6).

[4] Chiu, M. M. 2008. Flowing toward correct contributions during groups' mathematics problem solving; A statistical discourse analysis. Journal of the Learning Sciences, 17(3): $415-463$.

[5] Wang Xiaoping. 2014. Application for cooperative learning in senior high school English teaching. Middle School Students English, (8): 25-28.

[6] Du Fuzhen. 2013. How to improve cooperative learning in English teaching. Gansu Education, (8): 16-18.
[7] Guo Yanbing. 2002. Implementation and evaluation of cooperative learning in English classroom. Foreign Language Teaching in Primary and Secondary School, (9).

[8] Sharan, Y. 2010. Cooperative Learning for Academic and Social Gains: valued pedagogy, problematic practice. European Journal of Education, 45(2): 300-313.

[9] Jiang Xiaoling. 2002. Discussion of junior middle school English group cooperative learning. Foreign Language Teaching in Primary and Secondary School, (11).

[10] Bai Xiandong. 2012. To cultivate the students' interest in learning and improve the efficiency of vocational English teaching. Science Weekly, (3): 26-27.

[11] Li Bin. 2015. Thoughts on junior middle school English extracurricular activities. Course Education Research, (6). 